Vol 1 No 22020 Desember 2020

Jurnal AlphaEuclidEdu

Received: 21/10/2020; Revised: 28/11/2020; Accepted: 05/12/2020

\title{
PENGEMBANGAN INSTRUMEN EKSPLORASI KONSEP GEOMETRI BERSTRUKTUR DARI TEORI VAN HIELE BERBANTUAN SOFTWARE GEOGEBRA
}

\author{
${ }^{1}$ Pratikna, Dominicus Savio, ${ }^{2}$ Sugiatno, ${ }^{3}$ Hartoyo, Agung \\ 1,2,3 Pendidikan Matematika FKIP Universitas Tanjungpura Pontianak \\ Email:13savio@gmail.com
}

\begin{abstract}
The purpose of this study was to analyze the requirements of instrument, the characteristics of the developed questions prototype, the feasibility of the questions, and the thinking level of students regarding Van Hiele's Theory of geometry concept taught with assistance of Geogebra Software. This study was a Research and Development using Wina Sanjaya's model. The instrument' development procedure consists of four stages, namely: Preliminary Stage, Product Development Stage; Stage of Trial and Product Validation and Dissimination Stage of products. The instrument feasibility is based on the accuracy and practicality test. The subjects of this study were all students of class XI Santu Petrus Pontianak 2016/2017 Academic Year, with a sample of class XI-MIA3 students chosen randomly. The results showed the level of instrument feastibility which expressed through experts' testing and student' opinions, calculation of validity, reliability, distinguishing factors, levels of difficulty, and practicality test results. The instrument obtained an average validity of 0.68 belongs to high category, a reliability of 0.998 belongs to very high category, and a difficulty level of 0.35 belongs to moderate category. The percentage of content validity, construction and language content rated by the experts amounted to $91.16 \%$, which categorized as high. The student response rate was $80.9 \%$ which belong to good category.

Keywords: Instruments, Van Hiele's theory, Geogebra Software
\end{abstract}

\section{Pendahuluan}

Menurut Van De Walle (2008:149) bahwa pentingnya geometri untuk dipelajari, antara lain yaitu eksplorasi geometri memainkan peranan utama dalam bidang matematika lain dan digunakan banyak orang dalam kehidupan serta mempunyai tantangan dan menarik. Kennedy (2008:390) menyatakan bahwa pengetahuan, keterampilan geometri, kemampuan spasial, dan memecahkan masalah siswa dapat dikembangkan dengan mempelajari geometri. Dalam mempelajari geometri di sekolah perlu dikembangkan instrumen pembelajaran geometri yang mampu merangsang siswa untuk mencari sendiri, melakukan eksplorasi sendiri, melakukan pembuktian terhadap suatu dugaan yang mereka buat sendiri dan mencari tahu jawaban atas pertanyaan teman atau pertanyaan gurunya (Turmudi, 2008:25).

Dari pengamatan penulis pada umumnya pembelajaran dan instrumen tes geometri di kelas lebih bersifat konvensional dan kurang memberikan kesempatan luas kepada siswa untuk mengeksplorasi dan menemukan sendiri konsep-konsep geometri. Salah satu sebabnya belum tersedia materi pembelajaran dan instrumen yang memfasilitasi siswa bereksplorasi, serta terbatasnya pemakaian media pembelajaran berbasis teknologi untuk mempermudah proses bereksplorasi tersebut. Oleh karena konsepkonsep geometri sangat penting untuk dipelajari maka perencanaan pembelajaran 
Vol 1 No 22020 Desember 2020

Jurnal AlphaEuclidEdu

geometri perlu dirancang sebaik mungkin dengan memanfaatkan media pembelajaran dan instrumen geometri yang berbasis teknologi.

Pembelajaran dan pengembangan instrumen geometri berbasis teknologi ideal dimanfaatkan dalam mengeksplorasi konsep-konsep geometri. Dalam mengeksplorasi konsep-konsep geometri, perlu ketersediaan instrumen yang mampu mengeksplorasi konsep-konsep geometri. Instrumen tersebut disajikan secara terstruktur dan memerlukan tampilan grafis dengan ketepatan yang sangat baik dan cepat. Software Geogebra adalah Salah satu media yang berbasis teknologi. Sarana pada software Geogebra mendukung untuk mengaktifkan siswa mengeksplorasi konsep geometri dan meningkatkan pemahaman konsep geometri dengan baik. Penerapan software Geogebra pada pembelajaran dan pengembangan instrumen seiring dengan prinsip teknologi dari dokumen NCTM (2000: 24-27).

Dalam dokumen NCTM (2000: 24-27) dikembangkan bahwa peran teknologi sangat penting dalam pembelajaran matematika. Teknologi mampu berpengaruh terhadap matematika yang diajarkan dan mampu meningkatkan proses belajar siswa. Teknologi dapat membantu siswa untuk memfokuskan diri pada ide-ide matematika, pemahaman, dan mampu menyelesaikan persoalan matematika yang tidak mungkin dikerjakan tanpa bantuan teknologi. Dengan pemanfaatan teknologi banyak soal-soal matematika dapat dipecahkan dan memungkinkan siswa tertentu lebih efektif untuk memahami bagian matematika yang penting. Pembelajaran dengan memanfaatkan teknologi dapat meningkatkan proses belajar matematika karena dengan memanfaatkan teknologi siswa dapat bereksplorasi yang lebih luas dan memperbaiki penyajian ide-ide matematika terutama tentang konsep-konsep geometri. Pemanfaatan teknologi dalam pembelajaran geometri sangat mendukung terwujudnya tujuan pembelajaran geometri di kelas.

Tujuan pembelajaran geometri untuk siswa dibedakan dalam dua bagian yaitu bagian pertama berkaitan dengan cara siswa berpikir dan memahami bentuk dan ruang, dan bagian kedua berupa materi dalam pemahaman dalam mengetahui tentang simetri, segitiga, garis-garis sejajar, dan sebagainya (Van De Walle, 2008:150). Dalam dokumen NCTM (2000:29) juga menyatakan bahwa lima standar isi yang dipelajari siswa dalam belajar yaitu bilangan dan operasinya, aljabar, geometri, pengukuran, serta analisis data dan peluang, selain itu ada lima standar proses yaitu: pemecahan masalah, penalaran dan pembuktian, komunikasi, koneksi, serta representasi. Tujuan pembelajaran geometri seiring dengan standar isi dan standar proses dari dokumen NCTM (2000:29).

Semua standar NCTM (2000:41) mendukung pemikiran bahwa keterampilan dan pemahaman akan geometri dapat dikembangkan oleh semua siswa. Seiring dengan para pakar teori dan peneliti, gagasan dalam membangun pemahaman siswa tentang geometri dari pemikiran informasi ke lebih formal. Pembelajaran geometri berguna untuk meningkatkan berpikir logis dan menggeneralisasi secara baik dan benar. Penguasaan geometri yang baik dapat meningkatkan pemahaman aritmatika, aljabar, kalkulus dan 
Vol 1 No 22020 Desember 2020

Jurnal AlphaEuclidEdu

lain-lain lebih baik. Konsep-konsep geometri berperan sebagai alat pembelajaran geometri di sekolah.

Menurut Cockroft (dalam Turmudi 2008:15) bahwa pembelajaran geometri di pendidikan menengah dimulai dengan cara sederhana dari konkret, semikonkret, semi abstrak dan abstrak, dari segi intuitif ke analisis, serta dari tahap yang paling sederhana hingga yang kompleks. Pembelajaran geometri dapat dikatakan dari konsep yang paling mudah menuju konsep yang sukar. Penyajian abstraksi pada geometri memberikan pengalaman visual dan spasial, misalnya pola, pengukuran, bidang dan pemetaan.

Menurut dokumen NCTM (2000: 41), kemampuan geometri siswa kelas 9- 12 harus memiliki kemampuan visualisasi, menganalisis dan penalaran spasial. Keabstrakan objek yang dimiliki oleh Geometri, menuntut siswa untuk mampu menganalisis gambaran hubungan karakter, sifat-sifat geometri dan mampu membangun argumen-argumen mengenai hubungan geometri dengan hal-hal nyata baik yang dapat divisualisasikan maupun yang tidak dapat divisualisasikan. Dengan menvisualisasi konsep geometri dapat mempermudah belajar geometri (Guzman, 2002:9). Visualisasi merupakan hal yang penting dalam belajar geometri atau yang berkaitan dengan keruangan, atau analitis matematis yang lain. Visualisasi dapat memberikan visual suatu permasalahan dalam memecahkan masalah. Visualisasi konsep geometri sangat membantu untuk memahami konsep geometri itu sendiri. Adapun Wileman (dalam Sweeney, 2017:63) mendeskripsikan berpikir visual sebagai kemampuan mengubah informasi dari semua jenis ke dalam gambar, grafik, atau bentuk-bentuk visual lain yang dapat mengomunikasikan informasi. Visualisasi konsep geometri merupakan kemampuan mengubah bentuk informasi ke visual atau bentuk lain. Kemampuan visualisasi merupakan salah satu level berpikir dari Teori Van Hiele.

Van Hiele (dalam Bautista, 2016:1281) mengembangkan teori tingkat/level berpikir geometri. Ada lima tingkat/level berpikir dalam memahami geometri yaitu level (0) Visualisasi, level (1) Analisis, level (2) Deduksi Informal, level (3) Deduksi dan level (4) Rigor. Adapun menurut Van De Walle (2008:155) bahwa karakteristik terkait dengan tingkatan pemikiran yaitu (1) level-level tersebut bertahap, (2) Tingkatantingkatan tidak bergantung usia, (3) pengalaman geometri merupakan faktor tunggal terbesar dalam mempengaruhi perkembangan dalam tingkatan-tingkatan tersebut, (4) Ketika instruksi atau bahasa yang digunakan terletak pada tingkatan yang lebih tinggi daripada tingkatan berpikir siswa yang dimiliki, akan ada komunikasi yang kurang. Dari kelima level Teori Van Hiele, taraf kebutuhan visual geometri tidak semuanya sama. Kebutuhan visual pada level lebih tinggi semakin berkurang, bahkan visual dapat dihilangkan untuk tingkat Rigor. Namun visual geometri tetap diperlukan dalam belajar geometri. Hal tersebut berkaitan erat dengan pembelajaran matematika khususnya geometri dengan memanfaatkan Software Geogebra.

Software Geogebra dapat membantu dalam memahami konsep-konsep geometri dan dapat menghasilkan visual geometri dengan teliti dan akurat dibandingkan dengan menggunakan pensil, penggaris, dan jangka. Software Geogebra mampu memberikan 
Vol 1 No 22020 Desember 2020

Jurnal AlphaEuclidEdu

fasilitas animasi dan gerakan-gerakan manipulasi (dragging). Sehubungan dengan hal tersebut software Geogebra dimanfaatkan dalam mengembangkan instrumen eksplorasi konsep geometri pada materi transformasi geometri. Menurut Van De Walle (2008:150) bahwa cakupan materi geometri Sekolah Menengah Atas meliputi bentuk dan sifat, transformasi, lokasi dan visualisasi.

Dari cakupan materi geometri tersebut, secara spesifik peneliti memilih materi transformasi geometri untuk mengembangkan instrumen eksplorasi pemahaman geometri yang berstruktur Teori Van Hiele dengan berbantuan software Geogebra di SMA Santu Petrus Pontianak. Dari pengamatan penulis dan wawancara guru, penguasaan materi transformasi geometri dari siswa SMA Santu Petrus masih belum dikuasai dengan baik sesuai dengan standar yang ditetapkan oleh pemerintah. Hasil temuan tersebut ternyata terkonfirmasi berdasarkan oleh Laporan Hasil Ujian Nasional Tahun 2016 Puspendik Kemendikbud menyatakan bahwa daya serap penguasaan kompetensi yang berkaitan dengan transformasi geometri tingkat kota Pontianak sebesar 29,14\%, tingkat Provinsi 27, 98\% dan tingkat nasional 36,80\%. Adapun daya serap penguasaan transformasi geometri oleh siswa di SMA Santu Petrus Pontianak pada Ujian Nasional Tahun 2016 sebesar 55,22\%. Daya serap ini tersebut tergolong relatif rendah. Rendahnya daya serap siswa dalam penguasaan materi transformasi geometri pada Ujian Nasional Tahun 2016 diduga penyebabnya antara lain belum tersedianya instrumen eksplorasi konsep transformasi geometri berbantuan software Geogebra dan strategi pembelajaran transformasi geometri yang digunakan tidak sesuai dengan tingkatan berpikir yang disarankan oleh teori berpikir Van Hiele.

Konsep-konsep transformasi geometri dapat divisualisasikan dengan berbantuan software geogebra. Konsep-konsep transformasi geometri dapat divisualisasi, dianalisis, dan dideduksi yang berstruktur Teori Van Hiele. Oleh sebab itu, transformasi geometri dapat sebagai materi pengembangan instrumen pada penelitian ini. Oleh karena itu peneliti ingin mengembangkan instrumen eksplorasi geometri berstruktur Teori Van Hiele berbantuan software Geogebra pada materi transformasi geometri.

\section{Metode Penelitian}

Metode dalam penelitian ini adalah metode penelitian dan pengembangan (Research and Development) yang ditujukan untuk menghasilkan perangkat instrumen eksplorasi konsep geometri berstruktur Teori Van Hiele berbantuan software Geogebra yang valid dan praktis. Penelitian ini dilakukan dalam empat tahap yaitu tahap memunculkan ide/gagasan dan studi pendahuluan, pengembangan produk, uji coba, dan validasi produk.

\section{Tahap Memunculkan Ide/Gagasan dan Studi Pendahuluan}

Pada tahap ini terdiri atas dua kegiatan yaitu kegiatan memunculkan ide/gagasan awal dan melaksanakan studi pendahuluan. Studi pendahuluan terdiri atas survei lapangan dan survei kepustakaan. Dari tahap pertama ini melahirkan produk awal sebagai embrio produk pendidikan yang hendak dikembangkan. 
Vol 1 No 22020 Desember 2020

Jurnal AlphaEuclidEdu

\section{Tahap Pengembangan Produk}

Pada tahap pengembangan produk ini yakni mengimplementasikan produk awal dan menilainya dari sudut pandang proses pada lokasi dan subjek penelitian yang sangat terbatas.

\section{Tahap Uji Coba}

Pada tahap ini dilakukan uji coba produk yang terdiri atas uji coba terbatas dan uji coba yang lebih luas. Yang dinilai dari uji coba ini adalah proses dan hasil belajar. Pada tahap ini diharapkan menghasilkan produk hipotetik.

\section{Tahap Validasi Produk}

Pada tahap validasi produk sebagai kegiatan pasca pengembangan yang terdiri atas kegiatan pengujian validasi produk untuk menilai keandalan produk hasil pengembangan dan kegiatan diseminasi serta pelaporan.

\section{Hasil Penelitian dan Pembahasan}

\subsection{Hasil Penelitian dan Analisis Data}

Hasil studi pendahuluan dan analisis kebutuhan perangkat instrumen yang digunakan untuk eksplorasi konsep Geometri berstruktur Teori Van Hiele di SMA Santu Petrus Pontianak terdiri atas studi pendahuluan dan pengembangan instrumen. Studi pendahuluan yang dilaksanakan meliputi survei lapangan dan studi pustaka. Survei lapangan penelitian ini meliputi identitas sekolah, tenaga pendidik sebanyak 54 guru terdiri dari 29 guru tetap yayasan dan 25 guru tidak tetap, 6 dari 7 guru matematika dalam pengembangan instrumen belum menggunakan software Geogebra, survei kondisi subjek penelitian, iklim sosial dan iklim psikologis, keadaan sarana dan prasarana terdapat 3 ruang laboratorium komputer dengan setiap ruang berisi 45 unit komputer dan setiap minggu terdapat 4 jam pelajaran komputer, cara belajar siswa terdapat sebagian besar siswa cara belajarnya di sekolah cenderung masih menggunakan hafalan dan kurang mengembangkan daya eksplorasi dan nalarnya dalam memecahkan masalah geometri. Kriteria ketuntasan minimal (KKM) dari penilaian hasil belajar siswa di SMA Santu Petrus pada mata pelajaran Matematika ditetapkan sebesar 70.

Pada pengembangan instrumen ini dilaksanakan analisis pendahuluan yang terdiri atas analisis karakteristik siswa, analisis kurikulum, analisis materi, analisis instruksional dan analisis kebutuhan terhadap instrumen. Karakteristik umur siswa SMA Santu Petrus pada rentang 16 tahun sampai dengan 19 tahun. Analisis kurikulum di SMA Santu Petrus menggunakan Kurikulum 2013 dan diperoleh bahwa kelas XI jurusan Matematika dan Ilmu Alam terdapat kompetensi dasar yang memuat konsep geometri yaitu Kompetensi Dasar yang menganalisis sifat-sifat transformasi geometri meliputi pergeseran, pencerminan, perputaran dan dilatasi dengan pendekatan koordinat. Pada analisis materi untuk mengidentifikasi materi geometri yang tercatum dalam kurikulum. Analisis kebutuhan instrumen didasarkan dari hasil wawancara dengan guru matematika yang mengajar dan pengamatan pada buku catatan siswa di SMA Santu Petrus. Berdasarkan pengamatan, instrumen yang dipergunakan guru untuk 
Vol 1 No 22020 Desember 2020

Jurnal AlphaEuclidEdu

mengeksplorasi konsep geometri belum berstruktur teori Van Hiele dan berbantuan Software Geogebra.

Dari studi pendahuluan dan analisis pendahuluan disusun instrumen awal sebagai produk awal (prototype 1) yang terdiri dari kisi-kisi soal, butir soal sebanyak 16 butir soal, apllet geogebra yang dirancang berstruktur teori tingkat berpikir Van Hiele, pedoman penskoran butir soal, dan alternatif jawaban yang akan dikembangkan lebih lanjut. Prototype 1 dikembangkan, diujicobakan dan dianalisis serta dilakukan perbaikan sehingga menjadi prototype 2 . Prototype 2 dilakukan ujicoba dan analisis serta perbaikan sehingga menjadi prototype 3 . Demikian juga prototype 3 dilakukan pengujian dan analisis produk serta perbaikan sehingga didapatkan produk yang diharapkan dengan kualitas baik.

Prototype 1 ini merupakan instrumen eksplorasi konsep geometri berstruktur dari Teori Van Hiele berbantuan Software Geogebra yang terdiri dari kisi-kisi soal, butir soal, pedoman penskoran dan alternatif jawaban yang difokuskan dari segi konten(isi), konstruksi dan bahasa. Kisi-kisi dari prototype 1 dibuat berdasarkan kompetensi dasar, indikator soal, dan Teori Tingkat Berpikir Van Hiele pada materi transformasi geometri kelas XI di SMA. Penyebaran instrumen disajikan pada Tabel 1 berikut:

Tabel 1 Penyebaran Instrumen

\begin{tabular}{llll}
\hline $\begin{array}{l}\text { Tingkat Berpikir Teori } \\
\text { Van Hiele }\end{array}$ & Tranformasi Geometri & Banyak Soal & Nomor Soal \\
\hline Level 0 Visualisasi & $\begin{array}{l}\text { Visualisasi obyek translasi, } \\
\text { refleksi garis, dilatasi dan rotasi }\end{array}$ & 5 soal & $1,2,3,4,5$ \\
\hline Level 1 Analisis & $\begin{array}{l}\text { Sifat-sifat translasi, refleksi garis, } \\
\text { dilatasi dan rotasi }\end{array}$ & 5 soal & $6,7,8,9,10$ \\
\hline $\begin{array}{l}\text { Level } 2 \\
\text { Informal }\end{array}$ & $\begin{array}{l}\text { Komposisi transformasi Translasi, } \\
\text { Refleksi garis, Rotasi, dan } \\
\text { Dilatasi }\end{array}$ & 3 soal & $11,12,13$ \\
\hline Level 3 Deduksi & $\begin{array}{l}\text { Kombinasi transformasi Translasi, } \\
\text { refleksi garis, Rotasi, dan Dilatasi }\end{array}$ & 3 Soal & $14,15,16$ \\
\hline
\end{tabular}

Pada Tabel 1 menunjukkan bahwa penyebaran instrumen pada level berpikir Teori VanHiele terdiri atas 5 level 0 visualisasi, 5 soal level 1 analisis, 3 soal level 2 deduksi informal dan 3 soal level 3 deduksi. Prototype I merupakan ujian tertulis dengan bentuk soal essay yaitu isian singkat dan uraian terbuka. Pada tahap One-to-one dilakukan ujicoba Prototype I sebanyak dua kali untuk menemukan kelemahan dan kemudian dilakukan revisi. Hasil revisi dari prototype 1 dinamakan prototype 2. Prototype 2 yang dihasilkan selanjutnya dilakukan uji coba pada tahap Small grup yang melibatkan 15 siswa kelas XI Jurusan Matematika dan Ilmu-ilmu Alam di SMA Santu Petrus Pontianak. Hasil penskoran uji coba Small grup kemudian dilakukan analisis kuantitatif yang meliputi analisis validitas empiris, reliabilitas, daya pembeda dan tingkat kesukaran. Dari analisis tersebut diperoleh kelemahan dari instrumen yang dipakai untuk dijadikan dasar merevisi prototype 2. Hasil perhitungan diperoleh satu soal 
Vol 1 No 22020 Desember 2020

Jurnal AlphaEuclidEdu

dengan validitas kategori sangat tinggi, 8 soal dengan validitas tinggi, 3 soal dengan validitas cukup/sedang dan 3 soal dengan validitas rendah, reliabilitas soal sangat tinggi, tingkat kesukaran 4 soal kategori mudah, 9 soal kategori sedang dan 3 soal kategori sukar, daya pembeda ada 2 soal dengan daya pembeda rendah, 8 soal daya pembeda sedang dan 6 soal daya pembeda tinggi. Kelemahan prototype 2 diperbaikan dan direvisi sehingga diperoleh prototype 3 . Karakteristik dari prototype 3 adalah perangkat soal yang telah tervalidasi dari segi konten(isi), konstruksi dan bahasa oleh para ahli, dapat terbaca dengan baik melalui uji keterbacaan dan telah diujicobakan dalam skala kecil sehingga diperoleh hasil perhitungan validitas, reliabilitas, tingkat kesukaran dan daya pembedanya. Prototype 3 ini selanjutnya diujicobakan pada subjek dengan kelompok yang lebih luas (field grup) yang melibatkan 36 siswa dari kelas XI Jurusan Matematika Ilmu Alam SMA Santu Petrus Pontianak. Kelemahan-kelemahan pada uji coba tahap field tes ini dipergunakan untuk menyempurnakan prototype 3 menjadi produk akhir dari penelitian ini. Hasil uji coba soal untuk ketepatan instrumen tahap field tes yang dapat dilihat dari validitas butir soal, reliabilitas, daya pembeda dan tingkat kesukaran. Hasil uji coba butir soal tahap field tes disajikan pada Tabel 2 sebagai berikut:

Tabel 2. Rekapitulasi Hasil Analisis Uji Coba pada Field Tes

\begin{tabular}{|c|c|c|c|c|}
\hline Soal & $\begin{array}{l}\text { Validitas } \\
\text { Empiris }\end{array}$ & Reliabilitas & $\begin{array}{l}\text { Daya } \\
\text { Pembeda }\end{array}$ & $\begin{array}{l}\text { Indeks } \\
\text { Kesukaran }\end{array}$ \\
\hline 1 & 0,45 & \multirow{16}{*}{0,998} & 0,11 & 0,50 \\
\hline 2 & 0,60 & & 0,13 & 0,47 \\
\hline 3 & 0,44 & & 0,15 & 0,39 \\
\hline 4 & 0,45 & & 0,15 & 0,35 \\
\hline 5 & 0,57 & & 0,20 & 0,40 \\
\hline 6 & 0,71 & & 0,21 & 0,49 \\
\hline 7 & 0,83 & & 0,43 & 0,38 \\
\hline 8 & 0,66 & & 0,21 & 0,38 \\
\hline 9 & 0,71 & & 0,21 & 0,51 \\
\hline 10 & 0,83 & & 0,26 & 0,38 \\
\hline 11 & 0,73 & & 0,25 & 0,30 \\
\hline 12 & 0,82 & & 0,33 & 0,24 \\
\hline 13 & 0,84 & & 0,35 & 0,23 \\
\hline 14 & 0,79 & & 0,33 & 0,22 \\
\hline 15 & 0,71 & & 0,25 & 0,17 \\
\hline 16 & 0,67 & & 0,22 & 0,15 \\
\hline
\end{tabular}

Berdasarkan Tabel 2 menunjukkan bahwa (i) hasil uji validitas Empiris butir soal terdapat 11 soal memiliki validitas dengan kriteria baik dan ada 5 soal dengan validitas cukup; (ii) hasil uji reliabilitas butir soal diperoleh nilai $\mathrm{r} 11=0,998$ yang tergolong kriteria sangat baik;(iii) daya pembeda terdapat 3 soal kriteria sangat baik, 2 butir soal kriteria cukup baik, ada 6 soal daya pembeda dengan kriteria rendah dan daya pembeda 
Vol 1 No 22020 Desember 2020

Jurnal AlphaEuclidEdu

kriteria jelek ada 5 soal. Berdasarkan hasil perhitungan daya pembeda tersebut, perlu dilakukan diadakan revisi soal sebanyak 4 butir soal. Revisi dilakukan pada Applet Geogebra; (iv) tingkat kesukaran butir soal ada 5 soal kriteria sukar dan 11 soal kriteria sedang.

Hasil uji kepraktisan terhadap soal lebih menekankan pada kemudahan dalam pembuatan instrumen, penggunaan instrumen, pemeriksaan dan penilaian serta efisien dari segi biaya dan tenaga. Pembuatan instrumen ini menggunakan Software Geogebra versi 5.0. Software Geogebra ini dapat diunduh secara gratis di internet. Software Geogebra dapat dioperasikan melalui komputer dan gadget.

Berdasarkan hasil perhitungan analisis butir soal pada field tes yaitu perhitungan analisis uji validitas, reliabilitas, daya pembeda dan tingkat kesukaran menunjukkan bahwa semua soal dapat dikatakan valid dengan reliabilitas sangat tinggi serta tingkat kesukaran sedang atau sukar. Adapun dari daya pembeda terdapat daya pembeda dengan kriteria sangat baik, cukup baik, rendah dan masih terdapat soal-soal yang memiliki daya pembeda dengan kriteria jelek. Penggunaan instrumen ini menekankan pada sarana dan prasarana penunjang, respon siswa dan penilaian guru. Instrumen ini menggunakan sarana komputer atau gadget dan Software Geogebra.

Analisis Tingkat Berpikir Siswa SMA tentang Konsep Geometri Berstruktur Teori Van Hiele. Instrumen penelitian ini diujicobakan pada 36 siswa kelas XI jurusan Matematika dan Ilmu-ilmu Alam di SMA Santu Petrus Pontianak. Menurut kriteria Usiskin (1982) tentang kriteria kelulusan di setiap tingkat berpikir geometri Teori Van Hiele adalah 60. Dari hasil ujicoba 36 siswa diperoleh banyaknya siswa pada perkembangan tingkat berpikir level (3) Deduksi ada 2 siswa; tingkat (2) Deduksi Informal sebanyak 11 orang; tingkat (1) Analisis sebanyak 24 siswa dan tingkat (0) sebanyak 34 siswa. Sedangkan masih ada 4 siswa yang belum pada level (0) Visualisasi dari Teori Van Hiele. Data tersebut disajikan dalam bentuk diagram garis pada Grafik 1:

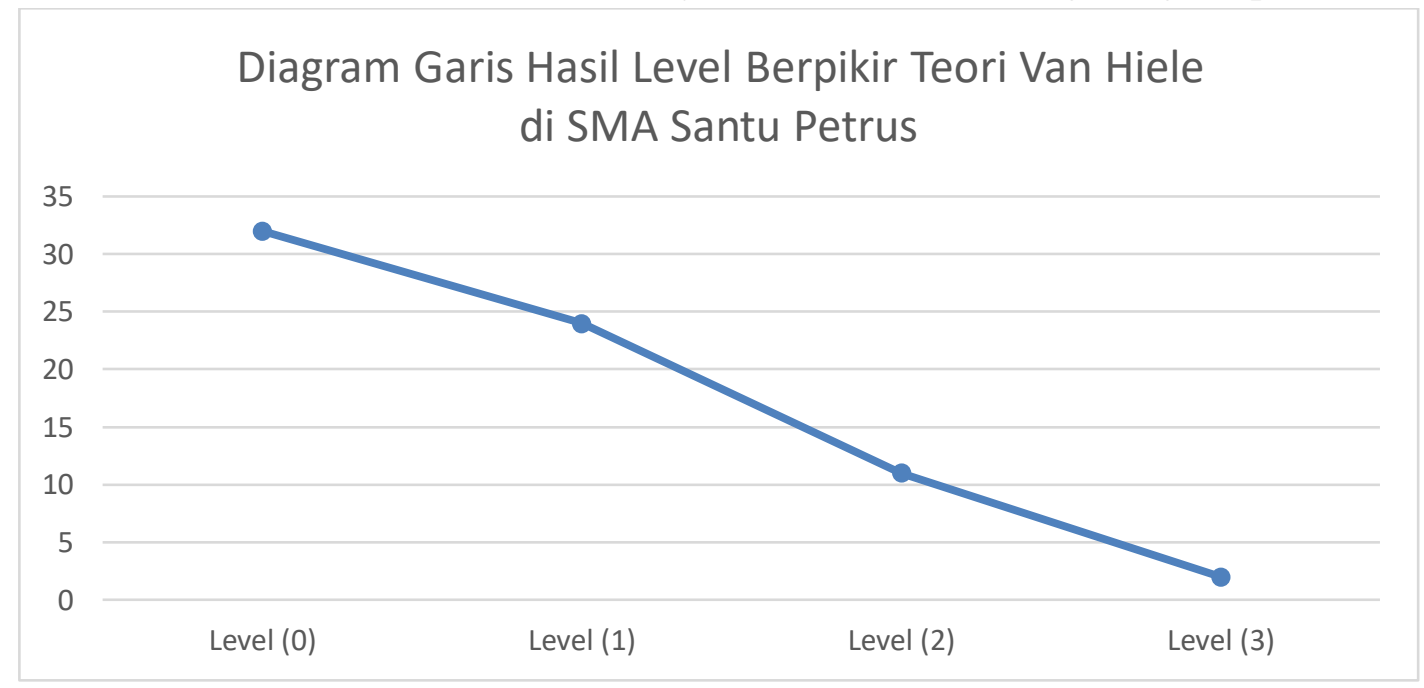

Grafik 1. Hasil Level Berpikir Teori Van Hiele siswa kelas XI MIA di SMA Santu Petrus

Tahun Pelajaran 2016/2017 
Vol 1 No 22020 Desember 2020

Jurnal AlphaEuclidEdu

Berdasarkan Grafik 1 menunjukkan bahwa grafiknya menurun dengan banyaknya siswa pada tingkat berpikir level 3 lebih sedikit dari level 2 atau level 1 atau level 0.

\subsection{Pembahasan Hasil Penelitian}

Pengembangan instrumen ini untuk mengetahui apakah instrumen yang ada di SMA Santu Petrus telah memenuhi kebutuhan untuk mengeksplorasi konsep geometri berstruktur Teori Van Hiele. Pengembangan instrumen ini didahului dengan studi pendahuluan, analisis pendahuluan dan pengembangan instrumen. Hal ini sejalan dengan pendapat Wina (2013:137-138), studi pendahuluan yang dilakukan berguna untuk memahami lebih dalam tentang ide/gagasan menciptakan produk yang sesuai dengan kebutuhan. Kegiatan ini perlu dilakukan untuk menjamin bahwa produk yang dihasilkan adalah produk yang berangkat dari kebutuhan, sehingga pada gilirannya produk yang dihasilkan bermanfaat di lapangan. Studi pendahuluan yang dilaksanakan pada penelitian ini meliputi survei lapangan dan studi pustaka. Survei lapangan ini untuk mendapatkan informasi tentang potensi sekolah yang terkait dengan pengembangan instrumen. Adapun survei lapangan dalam penelitian ini meliputi identitas sekolah, tenaga pendidik, perangkat instrumen matematika, survei kondisi subjek penelitian, cara belajar siswa, iklim sosial dan iklim psikologis, keadaan sarana dan prasarana, dan sistem evaluasi yang digunakan di lapangan. SMA Santu Petrus beralamatkan di Jalan Karel Satsuit Tubun Nomor 3 Pontianak yang merupakan salah satu sekolah berakreditasi A sebagai pelaksana terbatas Kurikulum 2013 sejak tahun 2012 dan pelaksana Ujian Nasional Berbasis Komputer (UNBK) sejak tahun 2016.

Tenaga pendidik di SMA Santu Petrus sebanyak 56 orang terdiri dari 29 guru tetap yayasan, 25 guru tidak tetap yayasan. Guru yang mengasuh mata pelajaran matematika sebanyak 7 orang yang terdiri dari 5 guru dengan masa kerja lebih 5 tahun dan 2 guru matematika kurang dari 5 tahun. Siswa di SMA Santu Petrus pada tahun pelajaran 2016/2017 sebanyak 1225 siswa yang terbagi dalam 31 rombongan belajar. Perbandingan banyaknya guru matematika dan siswa adalah 1: 175. siswa kelas $X$ sebanyak 392 siswa dan terbagi 10 rombongan belajar, kelas XI sebanyak 483 siswa dengan 12 rombongan belajar dan kelas XII sebanyak 350 siswa dengan 9 rombongan belajar. Banyaknya siswa laki-laki dengan perempuan cukup berimbang yaitu 618 siswa laki-laki dan 607 siswa perempuan. Sebagian besar siswa berdomisili di kota Pontianak dengan persentase sebesar $82 \%$ dan $18 \%$ di luar kota Pontianak. SMA Santu Petrus menggunakan Kurikulum 2013 dengan dua jurusan yaitu jurusan Matematika dan Ilmuilmu Alam (MIA) dan Ilmu-ilmu Sosial (IS). Pada Kurikulum 2013 mata pelajaran Teknologi Informasi dan Komputer ditiadakan namun SMA Santu Petrus tetap memberikan Mata Pelajaran Teknologi Informasi dan Komputer (TIK) sebanyak 4 jampel seminggu yaitu 2 jampel untuk mata pelajaran Prakarya dan 2 jampel sebagai Ekstrakurikuler wajib. Banyak laboratorium komputer ada 3 ruangan dengan masingmasing ruang berisi 45 unit komputer. Sistem manajemen dan informasi sekolah berbasis google Classroom, google kalender, grup line dan berbasis website dengan alamat sekolah www.smapetrus.net. Pengumuman dari sekolah, materi pembelajaran 
Vol 1 No 22020 Desember 2020

Jurnal AlphaEuclidEdu

dan tugas-tugas dari dapat diakses melalui google Classroom, grup line dan berbasis website. Adapun penerima siswa baru di SMA Santu Petrus tanpa menggunakan seleksi yang ketat sehingga kemampuan siswa baru di SMA Santu Petrus sangat beranekaragam. Oleh sebab itu pembagian rombongan belajar siswa berdasarkan minat siswa serta sistem pemerataan kemampuan dan gender di masing-masing rombongan belajar. Hal ini membentuk iklim sosial dan iklim psikologis dengan ciri khas tersendiri. Peran wali kelas di SMA Santu Petrus dioptimalkan untuk pembinaan dan pendampingan siswa di masing-masing kelas agar tercipta kondisi belajar yang kondusif di kelas dan di luar kelas. Kriteria keberhasilan pembelajaran di SMA Santu Petrus diukur dari ketercapaian didasarkan pada ketercapaian standar kelulusan, kompetensi inti, dan kompetensi dasar pada masing-masing mata pelajaran dengan kriteria ketuntasan minimal (KKM) terendah sebesar 70.

Studi kepustakaan pada penelitian ini dilakukan untuk meningkatkan pemahaman secara teoritis tentang pengembangan instrumen. Studi kepustakaan dilakukan dengan membaca, mencari literatur dan memahami artikel, jurnal, buku-buku, dan penelitian terdahulu yang berkaitan dengan pengembangan instrumen ini.

Analisis pendahuluan meliputi analisis karakteristik siswa, analisis kurikulum, analisis materi, analisis instruksional dan analisis kebutuhan terhadap instrumen. Karakteristik siswa SMA Santu Petrus ditinjau dari perkembangan fisik, intelektual dan perilaku sosial sebagai berikut.

Berdasarkan data umur siswa SMA Santu Petrus Pontianak Tahun pelajaran 2016/2017 bahwa persentase banyaknya siswa berumur 16 tahun berjenis kelamin lakilaki sebanyak 15,84\% dan perempuan 14,94\%; siswa berumur 17 tahun berjenis kelamin laki-laki $19,59 \%$ dan perempuan 20,65\%; siswa berumur 18 tahun berjenis kelamin laki-laki 12,65\% dan perempuan 11,84\% sisnya berumur 15 tahun, 19 tahun dan 20 tahun sebesar 4,49\%. Berdasarkan data tersebut bahwa persentase tertinggi adalah siswa berjenis perempuan berumur 17 tahun yaitu 20,65\% dan laki-laki berumur 17 tahun sebesar 19,59\%. Karakteristik umur siswa berdasarkan jenis kelamin dan setiap tingkatan kelasnya di SMA Santu Petrus memiliki karakteristik tersendiri. Menurut data domisili siswa bahwa $82 \%$ siswa berdomisi di kota pontianak dan $18 \%$ siswa berdomisili di luar Kota Pontianak. Hal ini sebagian besar siswanya memiliki berkehidupan sehari-hari pada lingkungan di kota.

Tingkat Kelas dalam penelitian ini adalah tingkat kelas XI jurusan Matematika dan Ilmu Alam (MIA) dan Kompetensi Dasar aspek pengetahuan adalah KD 3.20. menganalisis sifat-sifat transformasi geometri (pergeseran, pencerminan, perputaran dan dilatasi) dengan pendekatan koordinat dan menerapkannya dalam menyelesaikan masalah dan kompetensi dasar aspek keterampilan adalah KD 4.15. menyajikan objek kontekstual, menganalisis informasi terkait sifat-sifat objek dan menerapkan aturan transformasi geometri dalam memecahkan masalah.

Analisis kebutuhan terhadap instrumen ini diperlukan menggali informasi kebutuhan guru terhadap instrumen eksplorasi konsep geometri berbantuan Software 
Vol 1 No 22020 Desember 2020

Jurnal AlphaEuclidEdu

Geogebra. Dari wawancara dengan guru matematika yang mengajar di SMA Santu Petrus diperoleh informasi bahwa dalam pembelajaran guru sudah pernah memberikan dan menggunakan soal-soal untuk mengeksplorasi konsep geometri namun soal-soal yang dipakai belum berstruktur teori van Hiele dan belum berbantuan Software Geogebra. Menurut guru bahwa soal-soal jenis eksplorasi memerlukan ketersediaan waktu yang cukup untuk melakukan penyelidikan. Hal ini sejalan dengan pendapat Turmudi (2008:3).

Dari hasil respon siswa dan wawancara dengan siswa bahwa pemakaian sofware Geogebra dapat membantu mempermudah menyelesaiakan soal-soal yang diberikan. Oleh karena itu, instrumen yang dikembangkan dapat mengeksplorasi konsep geometri yang berstruktur dari Teori Tingkat Berpikir Van Hiele dan berbantuan Software Geogebra dan dapat sebagai alat pengukuran pencapaian hasil belajar siswa dan memberikan gambaran/profil tingkat berpikir bidang goemetri yang dimiliki siswa berdasarkan Teori Van Hiele.

Karakteristik Instrumen Eksplorasi Konsep Geometri Berstruktur dari Teori Van Hiele berbantuan Software Geogebra di SMA sebagai berikut: pengembangan instrumen didahului dengan studi pendahuluan dan analisis pendahuluan dan disusun instrumen awal (prototype 1) sebagai produk awal. Prototype 1 terdiri dari kisi-kisi soal, butir soal dan applet geogebra, pedoman penskoran, dan alternatif jawaban. Prototype 1 ini ditelaah oleh rekan sejawat dari segi konten (isi), konstruksi, dan bahasa dan kemudian diujicobakan pada 6 siswa sebagai subjek penelitian. Prototype I merupakan seperangkat instrumen dirancang berstruktur dari teori tingkat berpikir Van Hiele berbantuan Software Geogebra. Banyaknya butir soal yang disusun ada 16 butir soal. Setiap butir soal terdiri dari dua bagian yaitu bagian pokok soal dan applet Geogebra. Instrumen ini terdiri 5 soal level 0 Visualisasi, 5 soal level 1 Analisis, 3 soal level 2 deduksi informal dan 3 soal level 3 deduksi menurut teori tingkat berpikir Van Hiele.

Ujicoba prototype I pada tahap One-to-one dilakukan sebanyak dua kali. Uji coba One-to-one tahap pertama diujikan pada tiga siswa. Hasil uji coba One-to-one tahap I menekankan uji keterbacaan dan proses pengerjaan instrumen. Temuan kelemahankelemahan dari ujicoba One-to-one tahap I dipergunakan untuk merevisi prototype I. Uji coba kedua pada tahap One-to-one ini melibatkan 3 siswa. Hasil temuan dari kelemahan yang ditinjau bukan hanya aspek konten, kontruksi dan bahasa namun juga dari aspek proses mengerjakan instrumen pada prototype I dan respon siswa. Prototype I yang telah diujicobakan dan dilakukan revisi pada tahap One-to-one kemudian divalidasi oleh pakar ahli. Pakar ahli pada kegiatan experts review dilakukan oleh dua guru matematika alumni S2 Pendidikan Matematika Universitas Tanjungpura dan seorang dosen S2 Pendidikan Matematika Universitas Tanjungpura. Hasil validasi experts review dari aspek konten diperoleh 91,47\% dengan kategori valid, aspek kontruksi sebesar 90,18\% dengan kategori sangat valid dan aspek bahasa sebesar 91,82\% dengan kategori sangat valid. Rata-rata validitas ketiga validator experts review pada prototype 1 sebesar 91,16\% dengan kategori sangat valid. Prototype 1 yang telah 
Vol 1 No 22020 Desember 2020

Jurnal AlphaEuclidEdu

divalidasi oleh pakar ahli dan dilakukan analisis serta dilakukan perbaikan sehingga diperoleh prototype 2. Prototype 2 selanjutnya dilakukan uji coba pada tahap Small grup yang melibatkan 15 siswa kelas XI Jurusan Matematika dan Ilmu-ilmu Alam di SMA Santu Petrus Pontianak. Seusai siswa mengerjakan soal, siswa tersebut mengisi angket dan menuliskan saran atau komentar. Jawaban siswa yang terkumpul dilakukan koreksi berdasarkan kunci jawaban dan pedoman penskoran. Hasil penskoran dilakukan analisis kuantitatif yang meliputi analisis validitas empiris, reliabilitas, daya pembeda dan tingkat kesukaran. Hasil perhitungan dari analisis kuantitatif diperoleh sebagai berikut; 1)ada satu butir soal memiliki validitas sangat tinggi, ada 8 butir soal dengan validitas tinggi dan validitas cukup ada 3 butir soal serta ada 3 butir soal dengan validitas rendah; 2) Soal memiliki reliabilitas sangat tinggi; 3) Tingkat kesukaran mudah ada 4 soal, sedang ada 7 soal dan sukar ada 3 soal; 4) daya pembeda minimum/rendah ada 2 soal, sedang ada 8 soal dan tinggi ada 6 soal.

Prototype 2 yang telah direvisi menjadi prototype 3 selanjutnya diujicobakan pada subjek dengan kelompok yang lebih luas (field grup) yang melibatkan 36 siswa. Hasil uji coba pada tahap ini dianalisa secara kuantitatif dan kualitatif. Analisis kuantitatif meliputi analisis validits empiris, reliabilitas, daya pembeda dan tingkat kesukaran soal. Analisis kualitatif dilakukan dengan mengamati subjek saat mengerjakan soal, melakukan wawancara dengan subjek, dan meminta respon siswa setelah mengerjakan soal. Kelemahan-kelemahan yang diperoleh dipergunakan untuk menyempurnakan prototype 3 menjadi produk akhir dari penelitian ini.

Penyempurnaan prototype 3 menjadi produk akhir meliputi perbaikan pada applet Geogebra dengan menambah obyek/gambar dan dilengkapi petunjuk pada applet Geogebra untuk beberapa soal tertentu saja. Produk akhir ini merupakan instrumen eksplorasi konsep geometri berstruktur dari Teori Van Hiele berbantuan Software Geogebra di SMA berisi kisi-kisi soal, seperangkat soal terdiri dari pokok soal dan file applet Geogebra sebanyak 16 soal, kunci jawaban dan pedoman penskoran. Karakteristik instrumen produk akhir sebagai berikut: (1) Validitas Empiris, terdapat 11 soal memiliki validitas dengan kriteria baik dan ada 5 soal dengan validitas cukup; (2) Reliabilitas butir soal sebesar nilai r11 $=0,998$ dengan kriteria sangat baik; (3) Daya Pembeda, ada 3 soal dengan daya pembeda sangat baik, daya pembeda dengan kriteria cukup baik ada 2 butir soal dan daya pembeda dengan kriteria rendah ada 6 soal dan daya pembeda kriteria jelek ada 5 soal; (4) Tingkat Kesukaran ada 5 soal kriteria sukar, ada 11 soal kriteria sedang.

Tingkat Berpikir Siswa SMA tentang konsep geometri berstruktur Teori Van Hiele sebagai berikut: Instrumen diujicobakan kepada 36 siswa kelas XI jurusan Matematika dan Ilmu-ilmu Alam di SMA Santu Petrus Pontianak diperoleh banyaknya siswa pada perkembangan tingkat berpikir level (3) Deduksi sebanyak 2 siswa; tingkat (2) Deduksi Informal sebanyak 11 orang; tingkat (1) Analisis sebanyak 24 siswa dan tingkat (0) visualisasi sebanyak 32 siswa. Sedangkan masih ada 4 siswa yang belum pada level (0) Visualisasi dari Teori Van Hiele. Hal ini dapat dikatakan bahwa semakin tinggi 
Vol 1 No 22020 Desember 2020

Jurnal AlphaEuclidEdu

tingkatan berpikir menurut Teori Van Hiele, banyaknya siswa semakin berkurang. Perubahan tersebut berbanding terbalik antara banyaknya siswa dan tingginya level/tingkatan berpikir geometri dari Teori Van Hiele.

\section{Kesimpulan}

Berdasarkan dari hasil penelitian dan analisis data yang diperoleh serta pembahasan, penulis menyimpulkan sebagai berikut:

1. Perangkat instrumen yang digunakan telah memenuhi kebutuhan untuk mengeksplorasi konsep geometri berstruktur Teori Van Hiele di Sekolah Menengah Atas.

2. Karakteristik perangkat instrumen yang dikembangkan pada penelitian ini adalah perangkat instrumen eksplorasi konsep geometri berstruktur dari Teori Van Hiele dengan berbantuan Software Geogebra yang terdiri dari kisi-kisi soal, pokok soal dan file applet Geogebra, pedoman penskoran, dan alternatif jawaban.

3. Perangkat instrumen yang dikembangkan telah divalidasi oleh pakar ahli, dianalisis ketepatan meliputi analisis validitas empiris, reliabilitas, daya pembeda, dan tingkat kesukaran. Hasil perhitungan validitas empiris diperoleh 11 soal dengan kriteria baik dan 5 soal dengan kriteria cukup; reliabilitas butir soal sebesar dengan kriteria sangat baik; daya pembeda diperoleh 3 soal dengan kriteria baik, 2 soal dengan kriteria cukup baik dan 6 soal dengan kriteria rendah serta 5 soal dengan kriteria jelek: tingkat kesukaran diperoleh 4 soal kriteria sukar, dan 8 soal kriteria sedang dan 4 soal kriteria mudah. Berdasarkan rekapitulasi hasil respon siswa diperoleh rata-rata persentase kesetujuan siswa sebesar $84 \%$. dan hasil respon siswa terhadap kontruksi soal sebesar $80 \%$ dan hasil respon siswa terhadap bahasa sebesar $81 \%$.

4. Hasil pengujian instrumen eksplorasi konsep Geometri berstruktur dari teori Van Hiele berbantuan software Geogebra kepada 36 subjek di SMA Santu Petrus tahun pelajaran 2016/2017 diperoleh informasi perkembangan tingkat berpikir visualisasi sebanyak 32 siswa, tingkat berpikir analisis sebanyak 24 siswa, tingkat berpikir deduksi informal sebanyak 11 orang dan tingkat berpikir deduksi ada 2 siswa serta masih ada 4 siswa yang belum mencapai pada tingkat berpikir Visualisasi. Hal ini dapat dikatakan bahwa banyaknya siswa yang berpikir dengan tingkatan semakin tinggi menurut Teori Van Hiele semakin berkurang.

\section{Referensi}

Bautista, Gerome H. 2016. An Assessment of Grade 8 Geometry Teaching Guide of the $\mathrm{K}$ to 12 Basic Education Program Based on Van Hiele Model of Geometric Thinking and Department of Education's Standards. Saint Mary's University, Nueva Vizcaya, Philippines. [online], tersedia: http://pubs.sciepub.com/education/4/18/6/index.html.

Crowley, Mary L..1987. The Van Hiele Model of The Development of Geometric Thought. Yearbook of NCTM. 
Vol 1 No 22020 Desember 2020

Jurnal AlphaEuclidEdu

Depdiknas.2008. Panduan Penulisan Butir Soal. Jakarta:Direktorat PSMA.

Guzman, Miguel de. 2002. The Role of Visualisation in Teaching and Learning of Mathematical Analysis. Universidad Complutense de Madrid. [online], tersedia: http://files.eric.ed.gov/fulltext/ED472047.pdf.

Hohenwarter, Markus. 2008. Teaching and Learning Calculus With Free Dinamic Mathematics Software GeoGebra. [online], tersedia: https://archive.geogebra.org/static/publications/2008-ICME-TSG16-CalculusGeoGebra-Paper.pdf.

Kennedy, Leonard M. Tipps, Steve, \& Johnson, Art. 2008. Guiding Childern's Learning of Mathematics. Belmont, USA: Thomson Wadsworth.

Mahmudi, A.2010. Membelajarkan Geometri dengan Program GeoGebra. Makalah dipresentasikan dalam Seminar Nasional Matematika dan Pendidikan Matematika Jurusan Pendidikan Matematika FMIPA UNY. [Online]. Tersedia: http://eprints.uny.ac.id/10483/1/P6-Ali\%20M.pdf.

NCTM. 2000. Principles and Standards for School Mathematics. Virginia: NCTM, Inc.

Putra, Nusa. 2015. Research Development-Penelitian dan Pengembangan: Suatu Pengantar. Jakarta: PT RajaGrafindo Perkasa.

Sugiono. 2016. Metode Penelitian dan Pengembangan (Research and Development/R\&D). Bandung: Penerbit Alfabeta.

Sumaryanta. 2015. Pedoman Penskoran. PPPPTK Matematika, Yogyakarta.

Sweeney, Susan. 2017. Integrating Visual Literacy Training into the Business Curriculum. A Case Study at Dublin Business School. School of Business and Law Dublin Business School Dublin, Ireland. [online], tersedia: https://dbsbusinessreview.ie/index.php/journal/article/view/7/6.

Tessmer, Martin.1993. Planning and Conducting Formative Evaluations. British Library.

Turmudi. 2008. Landasan Filsafat dan Teori Pembelajaran Matematika (Berparadigma Eksploratif dan Integratif). Jakarta : Leuser Cipta Pustaka.

Usiskin, Zalman. 1982. Van Hiele Levels and Achievement in Secondary School Geometry. CDASSG Project. National Inst. Of Education (ED), Washington, DC.

Van De Walle, John. A. 2008. Matematika Sekolah Dasar dan Menengah Jilid 2 Pengembangan Pengajaran. Jakarta: PT Erlangga.

Watson, Conoiah. 2012. A Comparison of Van Hiele Levels and Final Exam Grades of Students at The University of Southern Mississippi. The University of Southern Mississippi.

Wina Sanjaya. 2013. Penelitian Pendidikan, Jenis, Metode dan Prosedur. Jakarta: Kharisma Putra Utama.

Zulkardi. 2006. Formative Evaluation: What, Why, When, and How. [online], tersedia: http://www.oocities.org/zulkardi/books.html. 